Keywords:

Alternative biomass

Renewable energy

Thermal analysis

Ignition

Histórico:

Recebido 16/07/2016

Aceito 17/01/2017

Palavras chave:

Biomassa alternativa

Energia renovável

Análises térmicas

Ignição

Correspondência: depaulaprotasio@gmail.com

DOI:
Thiago de Paula Protásio', Mario Guimarães Junior², Seyedmohammad Mirmehdi', Paulo Fernando Trugilho', Alfredo Napoli ${ }^{3}$, Kátia Monteiro Knovack ${ }^{4}$

\section{COMBUSTION OF BIOMASS AND CHARCOAL MADE FROM BABASSU NUTSHELL}

ABSTRACT: In recent years, studies have examined the use of lignocellulosic wastes for energy generation. However, there is a lack of information on the combustibility of the residual biomass, especially the bark and charcoal of babassu nut. In this study, thermogravimetric analysis (TGA), differential thermal analysis (DTA) and differential scanning calorimetry (DSC) were used to achieve the following objectives: to evaluate the combustion of the residual biomass from the babassu nut; to evaluate the combustion of charcoal produced from this biomass, considering different final carbonization temperatures; and to determine the effect of the final carbonization temperature on the thermal stability of charcoal and on its performance in combustion. Thermal analyses were performed in synthetic air. In order to evaluate the characteristics of charcoal combustion and fresh biomass, the ignition temperature $\left(T_{i}\right)$, the burnout temperature $\left(T_{f}\right)$, characteristic combustion index $(S)$, ignition index $\left(D_{i}\right)$, time corresponding to the maximum combustion rate $\left(t_{p}\right)$, and ignition time $\left(t_{i g}\right)$ were considered. The combustion of the babassu nutshell occurred in three phases and it was observed that this lignocellulosic material is suitable for the direct generation of heat. The increase in the final carbonization temperature caused an increase in the ignition temperature, as well as in the burnout temperature, the ignition time and the time corresponding to the maximum combustion rate. The results indicate that the increase in the carbonization temperature causes a decrease in combustion reactivity and, consequently, the charcoals produced at lower temperatures are easier to ignite and exhibit better performance in ignition.

\section{COMBUSTÃO DA BIOMASSA E DO CARVÃO VEGETAL DA CASCA DO COCO BABAÇU}

RESUMO: Nos últimos anos, pesquisadores têm analisado o uso de resíduos lignocelulósicos para geração de energia. No entanto, há uma falta de informação sobre a combustibilidade da biomassa residual, especialmente a casca e o carvão vegetal do coco babaçu. Neste estudo foram utilizadas as análises termogravimétricas (TGA), térmica diferencial (DTA) e de calorimetria exploratória diferencial (DSC) para: avaliar a combustão da biomassa residual do coco babaçu; avaliar a combustão do carvão vegetal produzido a partir dessa biomassa, considerando diferentes temperaturas finais de carbonização; e verificar o efeito da temperatura final de carbonização na estabilidade térmica do carvão vegetal e no seu desempenho na combustão. As análises térmicas foram realizadas em atmosfera de ar sintético. Para avaliar as características da combustão do carvão vegetal e da biomassa in natura foi considerada a temperatura de ignição (Ti), a temperatura final da combustão (Tf), o índice característico da combustão $(\mathrm{S})$, o índice de ignição $(\mathrm{Di})$, o tempo correspondente à máxima taxa de combustão (tp) e o tempo de ignição (tig). A combustão da casca do coco babaçu ocorreu em três fases distintas e observou-se que esse material lignocelulósico apresenta aptidão para a produção direta de calor. $\mathrm{O}$ aumento da temperatura final de carbonização causou um aumento da temperatura de ignição, da temperatura final da combustão, do tempo de ignição e do tempo correspondente à máxima taxa de combustão. Os resultados indicam que $\circ$ aumento da temperatura de carbonização causa uma diminuição da intensidade da combustão e, consequentemente, os carvões produzidos em temperaturas mais baixas são mais fáceis de inflamar e apresentam melhor desempenho na ignição.






\section{INTRODUCTION}

Traditionally, wood is used as a bioenergy source by either direct complete combustion or the conversion into various biofuels by means of specific routes. However, in recent years, researchers have examined the use of lignocellulosic wastes for this purpose, because those plant materials also feature organic compounds that can be oxidized and generate energy in a sustainable and efficient manner. According to Sain et al. (20I5), maize, wheat, rice, and sugarcane are the four agricultural crops with the most production in the world as well as largest area under cultivation.

Therefore, studies on the use of alternatives biomass, for example, the babassu nut waste, have great potential to be used for energy generation (PROTÁSIO et al., 20I4a, 20I4b, 20I4c; REIS et al., 20I5). Babassu nutshell showed a high basic density and a suitable lignin content for the sustainable production of bioenergy and charcoal (PROTÁSIO et al., 20l4a). However, there is a lack of information on the combustibility of residual biomass, especially the bark and charcoal of babassu nut.

The babassu palm is an evergreen, heliophytic and pioneer tree and it is native to Brazil and other countries in the Americas. It references three distinct genera of the family Arecaceae: Scheelea, Attalea and Orbignya, but the species Orbignya phalerata Mart. is the most common and widespread (TEIXEIRA, 2008). Porro et al. (20I I) comment that the babassu nuts are grown for the removal of almonds for the manufacture of vegetable oil, being it's shell the main waste produced in the process.

The fruit is composed of $12 \%$ epicarp, $23 \%$ mesocarp, and $58 \%$ endocarp or core material, with $93 \%$ of the coconut considered waste (shell). Therefore, each ton of babassu has $930 \mathrm{~kg}$ of biomass residues that can be allocated to the direct generation of heat in the industrial or residential systems as well as for the production of charcoal (EMMERICH and LUENGO, 1996; DIAS et al., 2012). Regarding the availability of biomass from babassu for bioenergy use, Teixeira (2008) estimated a potential exceeding six million tons per year. Maranhão is the Brazilian state with the highest potential for utilization of energy from babassu biomass.

In addition, the charcoal of babassu nutshell has high values of apparent density and energy density, possesses chemical and energetic properties suitable for steel use, and can be considered as a potential replacement of wood charcoal (SILVA et al., 1986; EMMERICH; LUENGO, I996; PROTÁSIO et al., 20l4b). The charcoal from babassu coconut can be used for direct heat generation in other industrial segments; however, their combustibility or combustion performance should be studied.
Despite the known possibility of using biomass of babassu nut and charcoal produced for direct energy generation there is a shortage of information related to their combustibility. It is known that among the various processes for converting biomass into energy, direct combustion is a more commercially widespread process and it is the oldest, simplest, and most noteworthy way of obtaining heat.

Thermal analysis of thermogravimetric (TGA), differential thermal (DTA) and differential scanning calorimetry (DSC) are techniques widely used to evaluate the oxidation process or the biomass combustibility. They have been used to evaluate the decomposition of the organic components of biomass and charcoal. The objective is to verify the type of reaction (endothermic or exothermic), evaluating the performance of the oxidation of materials during the ignition phase (KAl et al., 20I I; LIU et al., 20I3; MAGDZIARZ; WILK, 20I3; LÓPEZ-GONZÁLEZ et al., 2013).

In this study, thermogravimetric analysis (TGA), differential thermal analysis (DTA) and differential scanning calorimetry (DSC) were used with the following aims: to assess the combustion of the residual biomass babassu nut; to evaluate the combustion of charcoal produced from such biomass while considering different final temperatures of carbonization; and to determine the effect of the final carbonization temperature on the thermal stability of charcoal and its performance in combustion.

\section{MATERIAL AND METHODS}

The three constituent layers of the babassu nut, i.e. the epicarp, mesocarp and the endocarp (Figure I), were used together.

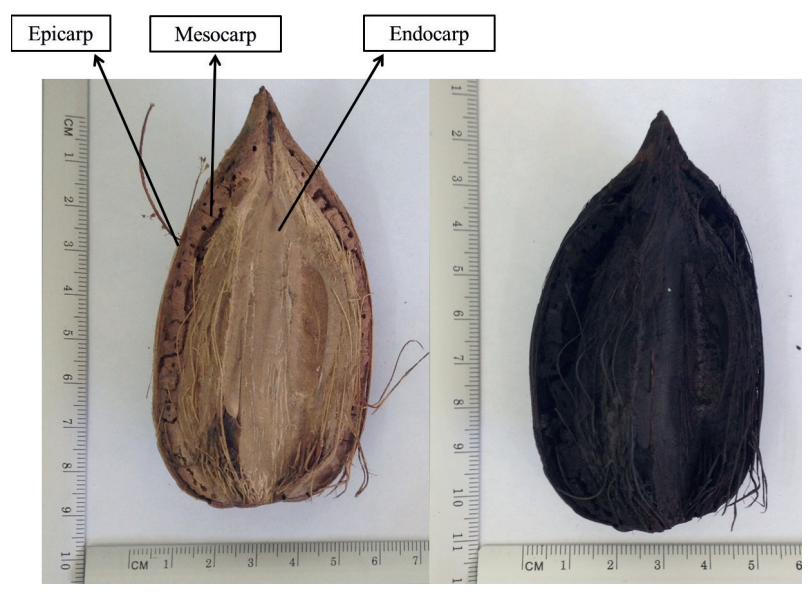

FIGURE I Fragments of babassu used for carbonization and charcoal obtained from the final temperature of $450^{\circ} \mathrm{C}$. 
The material was collected in the rural municipality of Sítio Novo do Tocantins, Tocantins State. Local communities obtain it from extractive exploitation. Babassu nutshell comes from manual breaking. The fresh biomass was processed in a hammer mill, homogenized and classified in sieves with 40,60 and 200-mesh.

Carbonization was performed in an electric furnace (muffle), with about $500 \mathrm{~g}$ of babassu nutshell used in each test. The samples were previously dried at $103 \pm 2{ }^{\circ} \mathrm{C}$. The initial temperature of the furnace was $100^{\circ} \mathrm{C}$ and the final temperatures of $450^{\circ} \mathrm{C}, 550^{\circ} \mathrm{C}$, $650^{\circ} \mathrm{C}, 750^{\circ} \mathrm{C}$ and $850^{\circ} \mathrm{C}$ were tested, considering a heating rate of $1.67^{\circ} \mathrm{C} \cdot \mathrm{min}^{-1}$. The temperature of the furnace remained stable for 30 minutes during the final phase. The total time of carbonization was $4 \mathrm{~h}, 5 \mathrm{~h}, 6 \mathrm{~h}, 7$ $\mathrm{h}$, and $8 \mathrm{~h}$ at the temperatures of $450^{\circ} \mathrm{C}, 550^{\circ} \mathrm{C}, 650^{\circ} \mathrm{C}$, $750^{\circ} \mathrm{C}$ and $850^{\circ} \mathrm{C}$, respectively.

For charcoal derived from babassu nutshell and for each final temperature, four replications were performed. The procedure used in the laboratory for carbonization is similar to that found in the literature for wood (ASSIS et al., 20I2; PROTÁSIO et al., 20I3).

The charcoal was duly crushed and classified into sieves of 40, 60 and 200-mesh, considering the four composite samples repetitions to perform the thermal analysis (DSC, TGA and DTA). Charcoal samples with particle size fraction that passed through 60-mesh sieve and were retained on the 200-mesh sieve were used for thermogravimetric analysis (TGA), differential thermal analysis (DTA) and differential scanning calorimetry (DSC). The thermal analysis (TGA and DTA) was performed on a synthetic air atmosphere (flow rate of $100 \mathrm{ml} \mathrm{min}^{-1}$ ) with SDT 2960 Simultaneous DTA-TGA units from TA Instruments, using $6 \mathrm{mg}$ of samples and a temperature that ranged from room conditions to $1,000^{\circ} \mathrm{C}$, with a heating rate of $10^{\circ} \mathrm{C} \cdot \mathrm{min}^{-1}$.

For fresh biomass or babassu nutshell, the thermal analysis was performed up to approximately $550^{\circ} \mathrm{C}$. From this temperature onwards there is no more potential for oxidizing organic matter. Using the first derivative of the TGA curve (DTG) it was possible to identify the rate of weight loss per minute and the characteristic stages of combustion of fresh biomass and also for charcoal obtained.

The differential scanning calorimetry test was conducted only for fresh biomass, using the DSC 2010 of TA Instruments equipment. Samples of $2 \mathrm{mg}$ were placed in aluminum containers. A standard sample used the empty container. The thermograms were obtained from room temperature to $550^{\circ} \mathrm{C}$, with a heating rate of $10^{\circ} \mathrm{C} \mathrm{m^{-1 }}$ and a synthetic air flow of $70 \mathrm{~mL} \cdot \mathrm{min}^{-1}$.
The ignition temperature $\left(T_{i}\right)$, the burnout temperature $\left(T_{f}\right)$, the characteristic combustion index $(S)$, the ignition index $\left(D_{i}\right)$, the time corresponding to the maximum rate combustion $\left(t_{p}\right)$, the ignition time $\left(t_{i g}\right)$, the maximum combustion rate and the average rate of combustion were considered.

In this study, the ignition temperature $\left(T_{i}\right)$ was defined as the temperature at which the combustion rate increased to I wt.\%.min ${ }^{-1}$ at the start of a major combustion process. The burnout temperature $\left(T_{f}\right)$ was defined as the temperature at which the combustion rate decreased to I wt.\%.min $\mathrm{m}^{-1}$ at the end of a combustion process (MOON et al., 20l3; WANG et al., 20ll; WANG et al., 20I2).

The combustion characteristic index (S) was obtained by Equation [I] (QIAN et al., 20I2; LI et al., 20I3; LIU et al., 20I3; MOON et al., 20I3), where: (dm/ $\mathrm{dt})_{\max }$ is the maximum combustion rate $\left(\% \cdot \mathrm{min}^{-1}\right) ;(\mathrm{dm} / \mathrm{dt})$ average is the average rate of combustion; $T_{i}$ is the ignition temperature $\left({ }^{\circ} \mathrm{C}\right), \mathrm{T}_{\mathrm{f}}$ is the burnout temperature $\left({ }^{\circ} \mathrm{C}\right)$.

$S=\frac{\left(\frac{d m}{d t}\right) \max \left(\frac{d m}{d t}\right) \text { average }}{\tau: 2 \ldots T s}$

The ratio of ignition ( $\mathrm{Di}$ ) was obtained by Equation [2] (XIANG-GU et al., 2006), where: (dm/dt) ${ }_{\max }$ is the maximum combustion rate $\left(\% \cdot \mathrm{min}^{-1}\right) ; \mathrm{t}_{\mathrm{p}}$ is the corresponding to the maximum combustion rate (min) and $\mathrm{t}_{\mathrm{ig}}$ time is the time from ignition (min.).

$D i=\frac{\left(\frac{d m}{d t}\right) \max }{t p x t i g}$

In order to better understand the combustion of fresh biomass and charcoal, chemical analysis was performed to quantify the levels of volatile materials (VM) and fixed carbon (FC) according to (ASTM D 1762, 1984).

\section{RESULTS AND DISCUSSION}

\section{Fresh biomass}

It is observed that the ignition temperature $\left(T_{i}\right)$ of babassu nutshell was $240.35^{\circ} \mathrm{C}$ and the burnout temperature $\left(T_{f}\right)$ was $433.86^{\circ} \mathrm{C}$ (Figure 2). These temperatures are considerably lower than those for charcoal (SAHU et al., 20I0), because the relative volatile/ fixed carbon from the bark of the babassu nut is high (3.95). Thus it has been observed that the ignition time of the fresh biomass was low (22.8 $\mathrm{min}$ ), the maximum and mean combustion rate were high and equal to $24.2246 \% \cdot \mathrm{min}^{-1}$ and $1.8498 \% \cdot \mathrm{min}^{-1}$, respectively. 




FIGURE 2 A curves and DTG combustion of fresh babassu nutshell.

The combustion characteristic index $(\mathrm{S})$ and the index of ignition $\left(D_{\mathrm{i}}\right)$ were also high: $17.88 \times 10^{7} \%{ }^{2} /\left(\mathrm{min}^{2}\right.$ ${ }^{\circ} \mathrm{C}^{3}$ ) and $25.74 \times 10^{3} \% \mathrm{~min}^{-3}$, respectively, and demonstrate the performance of the babassu nutshell during the combustion process. Sahu et al. (2010) evaluated the ignition of the pyrolyzed rice husk at $450^{\circ} \mathrm{C}$ and found $D_{i}$ rate of $3.54 \times 10^{3} \% \mathrm{~min}^{-3}$, lower than what was found for the fresh biomass babassu nut. This result demonstrates the ease of ignition of the studied lignocellulosic material compared to the charcoal of rice husk.

Three stages of thermal degradation of fresh biomass were observed. The first stage occurs from room temperature to $125^{\circ} \mathrm{C}$ and drying of the sample corresponds to a peak weight loss at $49.39^{\circ} \mathrm{C}$. In this phase the mass loss is related to the moisture content of $14.05 \%$.

The second stage, the devolatilization of the major components of biomass ( $\mathrm{LI}$ et al., 20/3), begins immediately after a period of thermal stability and extends up to about $360^{\circ} \mathrm{C}$, with a thermal degradation peak at $292.35^{\circ} \mathrm{C}$. A similar result was observed by Fernandes et al. (2013) to partially dried banana leaves. The authors observed a peak in the devolatilization step at $300^{\circ} \mathrm{C}$. Magdziarz and Wilk (2013), analyzing wood pellets, observed that this phase lasted until $350^{\circ} \mathrm{C}$. López-González et al. (2013) observed that the degradation peak of the Eucalyptus occurs at $290^{\circ} \mathrm{C}$ by thermogravimetric analysis in synthetic air atmosphere.

The devolatilization phase corresponding to the degradation of hemicelluloses, cellulose and part of lignin results in the release of volatiles and ignition (homogeneous combustion) and leads to the formation of the charcoal (MAGDZIARZ; WILK, 2013; KAl et al., 20I I; FERNANDES et al, 20I3). Thus, the rate of weight loss of the sample was high, since carbohydrates have low resistance to thermal degradation. The weight loss at this stage was $58 \%$. According to López-González et al. (2013), between the temperatures of $180^{\circ} \mathrm{C}$ and $388^{\circ} \mathrm{C}$, rapid degradation of hemicelluloses and cellulose occurs because the sugars in plant biomass degrade at low temperatures, confirming the results found for the shell of the babassu nut. The high cellulose content promotes greater devolatilization and increases the rate of thermal decomposition at lower temperatures (KAl et al., 20 I I).

During the third stage, there is a narrow peak at $428.41^{\circ} \mathrm{C}$ that relates to the decomposition of residual lignin oxidation and burning of fixed carbon formed on the second and third phases. This stage corresponds to the homogeneous combustion of released gases by the decomposition of lignin and heterogeneous combustion of solid carbon (MAGDZIARZ; WILK, 20I3; MOON et al., 20I3; KAl et al., 20I I; FANG et al., 2006).

Therefore, in this phase the mass loss was lower than the previous stage, corresponding to $25.79 \%$. We observed also a small shoulder at $406.95^{\circ} \mathrm{C}$ corresponding to the transition from the combustion of cellulose and lignin (REH et al., 1986). Lignin is the major contributor at this stage. It is the primary biomolecule responsible for the formation of charcoal due to its higher thermal stability compared to cellulose and hemicelluloses. The lignin macromolecule presents $\mathrm{C}-\mathrm{C}$ linkages between phenylpropane units, which result in thermal stability of its predominantly aromatic structure (KAI et al., 20II; SANCHEZ-SILVA et al., 20I2; GANI; NARUSE, 2007; YANG et al., 2007; SHARMA et al., 2004).

Kai et al. (20I I) observed that combustion of lignin occurs in a wide temperature range $\left(152^{\circ} \mathrm{C}\right.$ to $700^{\circ} \mathrm{C}$ ), but the rate of weight loss at lower temperatures is minimal (LÓPEZ-GONZÁLEZ et al., 20l3). Thus, the solid fraction resulting from combustion of this macromolecule is approximately $9 \%$ higher than the other structural components of plant biomass (KAl et al., $20 \mathrm{II})$. Furthermore, the fixed carbon is the fraction of the fuel that burns in the solid state and, thus, provides major thermal stability and less weight loss of the biomass during of the combustion (PROTÁSIO et al., 20I3).

The inorganic matter (ash) from the burning babassu is approximately $2 \%$. This value can be considered low compared to coal widely used around the world for the generation of electricity in thermal power plants and home heating. Ward et al. (2008) reported ash content of up to $21.4 \%$ in samples of coal. By chemical analysis the obtained value was $1.73 \%$, which is close to that observed by thermogravimetric analysis.

It is observed in Figure 3 and Figure 4 an endothermic phase related to the energy required for 


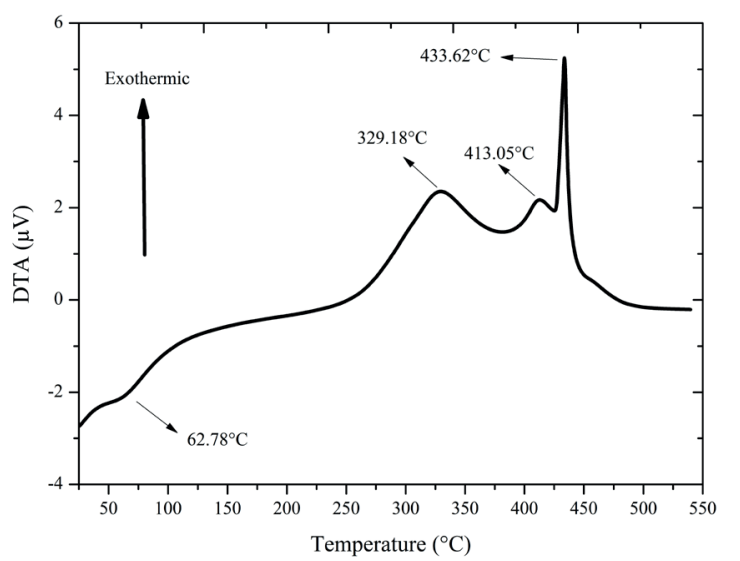

FIGURE 3 Differential thermal analysis (DTA) of combustion of fresh babassu nutshell.



FIGURE 4 Differential scanning calorimetry (DSC) from combustion of fresh babassu nutshell.

the evaporation of the moisture in the sample, with a peak at $62.78{ }^{\circ} \mathrm{C}$ (Figure 3) and $51.84{ }^{\circ} \mathrm{C}$ (Figure 4) for the differential thermal analysis and differential scanning calorimetry, respectively. From $250^{\circ} \mathrm{C}$, the reaction becomes exothermic for both analyses due to the release of energy by the combustion of organic matter. Fernandes et al. (2013) observed for banana leaves intended for energy use, exothermic reactions at $150^{\circ} \mathrm{C}$ for both dry and humid samples. Possibly, this was due to the lower thermal stability of this lignocellulosic waste compared to the babassu nutshell.

For the DTA curve two maximum temperature of combustion of the babassu nutshell in $329.18^{\circ} \mathrm{C}$ and $433.62^{\circ} \mathrm{C}$ and a lower peak in $413.0^{\circ} \mathrm{C}$ points are observed. The first peak can be attributed to the combustion of cellulose and hemicelluloses by means of the formation and emission of volatile (TSUJIYAMA; MIYAMORI, 2000). The transition from the combustion of the residual cellulose and lignin occurs, resulting in a smaller peak. After this phase intense degradation and oxidation lignin and fixed carbon occurs.

Fernandes et al. (2013) observed two exothermic events for combustion of banana leaves. The authors observed the first event between $150^{\circ} \mathrm{C}$ and $400^{\circ} \mathrm{C}$ and attributed it to the burning of the hemicelluloses and cellulose and second event between $400^{\circ} \mathrm{C}$ and $500^{\circ} \mathrm{C}$, characteristic of the combustion of the lignin, which corroborates with this work. It is observed that the peaks that are found in the DTA curve correspond to those found in the TGA and DTG curves (Figure 2), that is, as the sample loses mass, intense energy release occurs, since the breakage occurs in biomolecules and the chemical oxidation of the main fuel elements $(\mathrm{C}$ and $\mathrm{H})$.

Similar to that found in the DTA curve shape, we observed three well-defined exothermic peaks for the DSC curve at $333.36^{\circ} \mathrm{C}, 426.49^{\circ} \mathrm{C}$ and $459.90^{\circ} \mathrm{C}$ related to the combustion of babassu nutshell (Figure 4). Certainly, the first two peaks are mainly related to the energy released by the decomposition of cellulose and hemicelluloses in volatiles and the third peak to the energy released by the decomposition of the fixed carbon and residual lignin.

For the combustion of the Pinus densiflora wood, Tsujiyama and Miyamori (2000) observed in the DSC curve two main peaks at $340^{\circ} \mathrm{C}$ and $475^{\circ} \mathrm{C}$ and a minor peak at $450^{\circ} \mathrm{C}$, which is similar to our findings. It is noteworthy that the differences found for the peak temperatures in the DTA and DSC curves can be attributed to the different techniques used, but the trends found are similar.

\section{Charcoal from babassu nutshell}

It is observed, in Figure 5, that in the initial stage of combustion of the fuel (drying) there is a tendency of increase mass loss for charcoals produced at higher temperatures $\left(650^{\circ} \mathrm{C}, 750^{\circ} \mathrm{C}\right.$ and $\left.850^{\circ} \mathrm{C}\right)$ compared to the charcoals obtained at lower temperatures $\left(450^{\circ} \mathrm{C}\right.$ and $550^{\circ} \mathrm{C}$ ). This was assumed to be due to increased hygroscopicity, consequently, the moisture of charcoal increased with the increasing of final carbonization temperature, corroborating the results of Vilas Boas et al. (2010).

After the drying phase there is an increase in the thermal stability of the charcoal with increasing final temperature of carbonization, thereby resulting in a shift of the maximum peak of weight loss for the regions of high temperature (Figure 6). In addition, there are increases in ignition temperature and burnout temperature of the fuel (Figures 7 and 8 ) and a decrease of the characteristic combustion index and ignition index (Table I). 




FIGURE 5 TGA curves of combustion of charcoal from babassu nut residues produced at different final temperatures of carbonization.



FIGURE 6 DTG curves of combustion of charcoal from babassu nut residues produced at different final temperatures of carbonization.



FIGURE 7 Relationship between the ignition temperature and the volatile/fixed carbon of charcoal produced at different carbonization temperatures.



FIGURE 8 Ratio of burnout temperature and the relative volatile/fixed carbon charcoal produced at different carbonization temperatures.

The characteristic combustion index $(\mathrm{S})$ reflects the reactivity of the combustion of the charcoal throughout the oxidation reaction and the higher this ratio the better the performance of the fuel during of the combustion (QIAN et al., 20I2; XIONG et al., 20I4). Therefore, the charcoal with the highest ignition index is easier to ignite (QIAN et al., 20I2).

Xiong et al. (2014) also observed an increase in the ignition temperature and the burnout temperature and a decrease in the combustion characteristic rate with increasing final temperature of carbonization for sawn bamboo, corroborating the findings of this study.

In addition, the average rate of combustion of the charcoals produced with higher temperatures $\left(650^{\circ} \mathrm{C}, 750^{\circ} \mathrm{C}\right.$ and $850^{\circ} \mathrm{C}$ ) was lower than the for charcoals produced at $450^{\circ} \mathrm{C}$ and $550^{\circ} \mathrm{C}$. The higher average rate of combustion of the charcoal produced at $850^{\circ} \mathrm{C}$, in relation to the charcoals obtained at the temperatures of $650^{\circ} \mathrm{C}$ and $750^{\circ} \mathrm{C}$, can be explained by the lower ash content of the charcoal produced at high temperature (PROTÁSIO et al., 20l4b).

This result can be explained by the chemical constitution of charcoals, especially the ratios of volatile materials (VM)/fixed carbon (FC). It is known that there is a tendency to reduce the content of volatile materials and to increase the fixed carbon content and therefore decrease the VM/FC ratio with the increase of the final carbonization temperature (TITILADUNAYO et al., 2012; PROTÁSIO et al., 20I4a).

The greatest amount and the rapid emission of volatile materials are factors that contribute decisively to accelerate the ignition of the fuel at a lower temperature (MOON et al., 2013). Therefore, the decrease of the VM/ FC with increasing final temperature of carbonization explains the rise in time of ignition and rate corresponding to the highest combustion time and the decrease in $\mathrm{S}$ and $D_{i}$ indexes (Table I). 
TABLE I Characteristic parameters of combustion of charcoal from babassu nutshell

\begin{tabular}{cccccccc}
\hline $\begin{array}{c}\text { Temp } \\
\left({ }^{\circ} \mathrm{C}\right)\end{array}$ & $\mathrm{VM} / \mathrm{FC}^{2}$ & $\begin{array}{c}(\mathrm{dm} / \mathrm{dt})_{\max }{ }^{3} \\
\left(\% \cdot \mathrm{min}^{-1}\right)\end{array}$ & $\begin{array}{c}(\mathrm{dm} / \mathrm{dt})_{\text {average }}{ }^{4} \\
\left(\% \cdot \mathrm{min}^{-1}\right)\end{array}$ & $\begin{array}{c}\mathrm{tp}^{5} \\
(\mathrm{~min})\end{array}$ & $\begin{array}{c}\mathrm{tig}^{6} \\
(\mathrm{~min})\end{array}$ & $\begin{array}{c}\mathrm{S}^{6} 10^{7} \\
\%^{2} /\left(\mathrm{min}^{2}{ }^{\circ} \mathrm{C}^{3}\right)^{7}\end{array}$ & $\begin{array}{c}\mathrm{D}_{i} \times 10^{3} \\
\left(\% \mathrm{~min}^{-3}\right)^{8}\end{array}$ \\
\hline 450 & 0.30 & 22.9423 & 0.9548 & 38.5 & 30.0 & 4.93 & 19.86 \\
550 & 0.16 & 15.5070 & 0.9541 & 39.3 & 33.1 & 2.67 & 11.94 \\
650 & 0.09 & 15.9396 & 0.9129 & 40.5 & 35.7 & 2.28 & 11.04 \\
750 & 0.08 & 13.8978 & 0.9281 & 44.5 & 38.7 & 1.62 & 8.08 \\
850 & 0.07 & 15.3760 & 0.9337 & 48.1 & 40.8 & 1.56 & 7.82 \\
\hline
\end{tabular}

'Temp: final temperature of carbonization; ${ }^{2} \mathrm{VM} / \mathrm{FC}$ : volatile materials/fixed carbon ratio; ${ }^{3}(\mathrm{dm} / \mathrm{dt})$ max: maximum rate of combustion; ${ }^{4}(\mathrm{dm} / \mathrm{dt})$ average: average rate of combustion; ${ }^{5}$ tp: corresponding to the highest rate of combustion time; ${ }^{6}$ tig: ignition time; ${ }^{7} \mathrm{~S}$ : characteristic combustion index; ${ }^{8} \mathrm{Di}$ : ignition index.

These results indicate that the increase of carbonization temperature causes a decrease of the reactivity and consequently the charcoals produced at lower temperatures are easier to ignite and exhibit better performance concerning ignition (QIAN et al., 2012). The decrease in the rate of combustion characteristic $(s)$ and the ignition index $\left(D_{i}\right)$ indicates that the charcoals produced at lower temperatures show better combustibility and are more easily burned (QIAN et al., 20I2). Furthermore, it is observed that the charcoal produced at the final temperature of $450^{\circ} \mathrm{C}$ showed the highest maximum rate of combustion $\left(22.9423 \% \mathrm{~min}^{-}\right.$ '), due to the higher VM/FC ratio. When the charcoal is heated volatiles are emitted and mixed with oxygen in the air, promoting homogeneous combustion and increasing mass consumption.

Qian et al. (2012) evaluated samples of pyrolyzed coal at the final temperature of $450{ }^{\circ} \mathrm{C}, 550^{\circ} \mathrm{C}$ and 650 ${ }^{\circ} \mathrm{C}$ and found combustion characteristic indexes of $\mathrm{I} .24$ $\times 10^{-7}, 1.23 \times 10^{-7}$ and $9.40 \times 10^{-8} \%^{2} /\left(\mathrm{min}^{2}{ }^{\circ} \mathrm{C}^{3}\right)$. These values are considerably lower than those observed for the charcoal of babassu nut residue at the same final temperatures of pyrolysis. These comparisons show the great potential of using babassu nut for energetic purposes, especially for the direct generation of heat in residential or industrial systems.

For the rate of ignition, Xiang-guo et al. (2006) reported the value of $8.1 \times 10^{3} \mathrm{~min}^{-3} \%$ for coal, being lower than that observed for babassu nutshell charcoal produced at temperatures of $450^{\circ} \mathrm{C}, 550^{\circ} \mathrm{C}$ and $650^{\circ} \mathrm{C}$. This indicates greater ease of ignition of charcoal of babassu obtained in these final carbonization temperatures.

In Figure 9 can be see the differential thermal analysis of combustion of the charcoal babassu nutshell produced with different final carbonization temperatures. It is observed that from $222.56^{\circ} \mathrm{C}$, $251.95^{\circ} \mathrm{C}, 283.02^{\circ} \mathrm{C}, 277.23^{\circ} \mathrm{C}$ and $298.70 \mathrm{C}$, the reaction becomes exothermic for charcoal produced at temperatures $450^{\circ} \mathrm{C}, 550^{\circ} \mathrm{C}, 650^{\circ} \mathrm{C}, 750^{\circ} \mathrm{C}$ and $850^{\circ} \mathrm{C}$, respectively.

In general, there is a trend of increasing temperature at which the exothermic reactions are initiated depending on the final temperature of carbonization. As discussed previously for the TGA curves (Figure 5), this occurred due to increased moisture content of charcoals produced with higher increasing final temperature of carbonization.

By the DTA curves it is noted that there was only one exothermic peak and one main combustion stage for the charcoal (Figure 9). In addition, there was an increase in the peak of energy liberation as a function of the increase of the carbonization temperature. These peaks, in turn, correspond to the DTG curves (Figure 6). For charcoals produced in the final temperatures of $450^{\circ} \mathrm{C}$ and $650^{\circ} \mathrm{C}$ there was a slight exothermic peak at $446.30^{\circ} \mathrm{C}$ and $450.49^{\circ} \mathrm{C}$, respectively. This result can be attributed to co-combustion of the volatile materials and solid carbon.

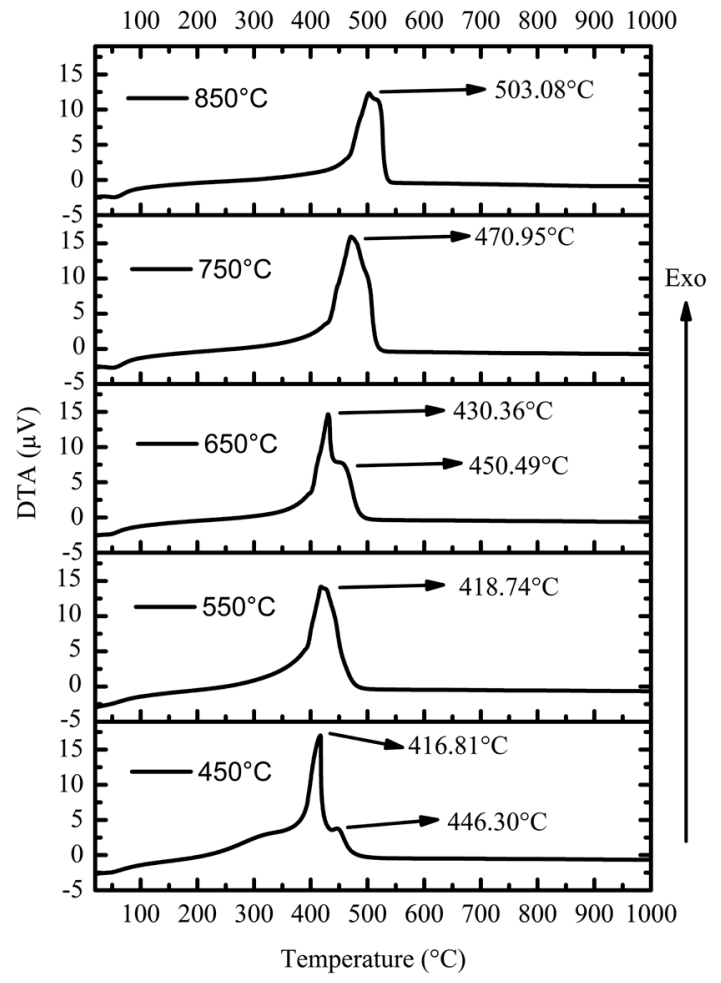

FIGURE 9 Differential thermal combustion analysis (DTA) of babassu nutshell charcoal produced at different final temperatures of carbonization. 


\section{CONCLUSIONS}

The combustion of the babassu nutshell occurred in three distinct phases, and we observed that this lignocellulosic material shows aptitude for direct heat production, due to its low ignition temperature, high $\mathrm{S}$ and $D_{i}$ indexes and low ignition time.

After the drying phase, there is an increase in the thermal stability of the charcoal with increase of the final temperature of carbonization.

The increase of the final carbonization temperature increased the ignition temperature, the burnout temperature, the ignition time and the maximum rate of combustion time.

The average rate of combustion of the charcoals produced at higher temperatures $\left(650^{\circ} \mathrm{C}, 750^{\circ} \mathrm{C}\right.$ and $850^{\circ} \mathrm{C}$ ) was lower than that of the charcoals produced at $450^{\circ} \mathrm{C}$ and $550^{\circ} \mathrm{C}$.

The charcoals produced at higher temperatures present greater difficulty in combustion.

\section{ACKNOWLEDGMENTS}

CNPq (Conselho Nacional de Desenvolvimento Científico e Tecnológico) for granting the scholarship of the first author (process I3243I/20I3-0 and |4|439/20|4-9).

\section{REFERENCES}

AMERICAN SOCIETY FOR TESTING MATERIALS - ASTM D 1762- 84: standard test method for chemical analysis of wood charcoal. Philadelphia: ASTM International, 2007. $2 p$.

ASSIS, M. R.; PROTÁSIO, T. P.; ASSIS, C. O; TRUGILHO, P. F; SANTANA, W. M. S. Qualidade e rendimentos do carvão vegetal de um clone híbrido de Eucalyptus grandis $\mathrm{x}$ Eucalyptus urophylla. Pesquisa Florestal Brasileira, v.32, n.7I, p.29I-302, 2012.

DIAS, J. M. C. S.; SOUZA, D. T.; BRAGA, M.; ONOYOMA, M. M.; MIRANDA, C. H. B.; BARBOSA, P. F. D.; ROCHA, J. D. Produção de briquetes e péletes a partir de resíduos agrícolas, agroindustriais e florestais. Brasília, DF: Embrapa Agroenergia, 2012, 130p.

EMMERICH, F. G.; LUENGO, C. A. Babassu charcoal: a sulfurless renewable thermo-reducing feedstock for steelmaking. Biomass and Bioenergy, v.10, n.l, p.4I44. 1996.

FANG, M. X.; SHEN, D. K.; LI, Y. X.; YU, C. J.; LUO, Z. Y.; CEN, K. F. Kinetic study on pyrolysis and combustion of wood under different oxygen concentrations by using TG-FTIR analysis. Journal of Analytical and Applied Pyrolysis, v.77, n. I, p.22-27, 2006.
FERNANDES, E. R. K.; MARANGONI, C.; SOUZA, O.; SELLIN, N. Thermochemical characterization of banana leaves as a potential energy source. Energy Conversion and Management, v.75, p.603-608, 2013.

GANI, A.; NARUSE, I. Effect of cellulose and lignin content on pyrolysis and combustion characteristics for several types of biomass. Renewable Energy, v.32, p.649-66I, 2007.

KAI, X.; YANG, Y.; HUANG, Y.; SUN, Y. H. E. Y.; LI, R. The effect of biomass components on the co-combustion characteristics of biomass with coal. In: Digital Manufacturing and Automation, p. I274-1278, 20 I I.

LI, L.; ZHAO, N.; FU, X.; SHAO, M.; QIN, S. Thermogravimetric and kinetic analysis of Spirulina wastes under nitrogen and air atmospheres. Bioresource Technology, v. I40, p.I52157, 2013.

LIU, X.; CHEN, M.; YU, D. Oxygen enriched co-combustion characteristics of herbaceous biomass and bituminous coal. Thermochimica Acta, v.569, p. I7- 24, 2013.

LÓPEZ-GONZÁLEZ, D.; FERNANDEZ-LOPEZ, M.; VALVERDE, J. L.; SANCHES-SILVA, L. Thermogravimetricmass spectrometric analysis on combustion of lignocellulosic biomass. Bioresource Technology, v. I43, p.562-574, 2013.

MAGDZIARZ, A.; WILK, M. Thermogravimetric study of biomass, sewage sludge and coal combustion. Energy Conversion and Management, v.75, p.425-430, 2013.

MOON, C.; SUNG, Y.; AHN, S.; KIM, T.; CHOI, G.; KIM, $D$. Effect of blending ratio on combustion performance in blends of biomass and coals of different ranks. Experimental Thermal and Fluid Science, v.47, p.232240, 2013.

PORRO, N.; VEIGA, I.; MOTA, D. Traditional communities in the Brazilian Amazon and the emergence of new political identities: the struggle of the quebradeiras de coco babaçu babassu breaker woman. Journal of Cultural Geography, v.28, p.|23-|46, 201 I.

PROTÁSIO, T. P.; TRUGILHO, P. F; CÉSAR, A. A. S.; NAPOLI, A.; MELO, I. C. N. A.; SILVA, M. G. Babassu nut residues: potential for bioenergy use in the North and Northeast of Brazil. SpringerPlus, v. 3, p. I-I4, $2014 a$.

PROTÁSIO, T. P.; TRUGILHO, P. F.; MIRMEHDI, S.; SILVA, M. G. Quality and energetic evaluation of the charcoal made of babassu nut residues used in the steel industry. Ciência e Agrotecnologia, v.38, n.5, p.435-444, 2014b.

PROTÁSIO, T. P.; TRUGILHO, P. F.; NAPOLI, A.; SILVA, M. G.; COUTO, A. M. Mass and energy balance of the carbonization of babassu nutshell as affected by temperature. Pesquisa Agropecuária Brasileira, v. 49, n.3, p. 189-196, 2014c. 
PROTÁSIO, T. P.; MELO, I. C. N. A.; GUIMARÃES JUNIOR, M.; MENDES, R. F.; TRUGILHO, P. F. Thermal decomposition of torrefied and carbonized briquettes of residues from coffee grain processing. Ciência e Agrotecnologia, v.37, n.3, p.221-228, 2013.

QIAN, W, XIE.; Q, HUANG, Y.; DANG, J.; SUN, K.; YANG, Q.; WANG, J. Combustion characteristics of semicokes derived from pyrolysis of low rank bituminous coal. International Journal of Mining Science and Technology, v.22, n.5, p.645-650, 2012.

REH, U.; KRAEPELIN, G.; LAMPRECHT, I. Use of differential scanning calorimetry for structural analysis of fungally degraded wood. Applied Environmental Microbiology, v.52, n.5, p.II0I-I106, 1986.

REIS, A. R. S.; REIS, J. S. F.; SILVA, J. R.; CARVALHO, J. C.; SOUZA, D. V.; REIS, L. P. Comparação entre carvão de coco babaçu e carvão de resíduos madeireiros comercializados em Altamira - PA. Ciência da Madeira, v.6, n.2, p.100106, 2015.

SAHU, S. G.; SARKAR, P.; CHAKRABORTY, N.; ADAK, A. K. Thermogravimetric assessment of combustion characteristics of blends of a coal with different biomass chars. Fuel Processimg Technology, v.91, n.3, p.369378, 2010.

SAIN, J. K.; SAIN, R.; TEWARI, L. Lignocellulosic agriculture wastes as biomass feedstocks for second-generation bioethanol production: concepts and recent developments. 3 Biotech, v.5, n.4, p.337-353, 2015.

SANCHEZ-SILVA, L.; LÓPEZ-GONZALEZ, D.; VILLASEÑOR, J.; SÁNCHES, P.; VALVERDE, J. L. Thermogravimetricmass spectrometric analysis of lignocellulosic and marine biomass pyrolysis. Bioresource Technology, v.109, p. I63-172, 2012.

SHARMA, R. K.; WOOTEN, J. B.; BALIGA, V. L, LIN.; X, CHAN.; W. G, HAJALIGOL, M. R. Characterization of chars from pyrolysis of lignin. Fuel, v.83, n. II-12, p.146982, 2004.

SILVA, J. C.; BARRICHELO, L. E. G.; BRITO, J. O. Endocarpo de babaçu e de macaúba comparados a madeira de Eucalyptus grandis para a produção de carvão vegetal. IPEF, n.34, p.3I-34, 1986.
TEIXEIRA, M. A. Babassu - a new approach for an ancient Brazilian biomass. Biomass Bioenergy, v.32, n.9, p.857864, 2008.

TITILADUNAYO, I. F; MCDONALD, A. G.; FAPETU, O. P. Effect of temperature on biochar product yield from selected lignocellulosic biomass in a pyrolysis process. Waste and Biomass Valorization, v.3, n.3, p.3। I-3।8, 2012.

TSUJIYAMA, S. I.; MIYAMORI, A. Assignment of DSC thermograms of wood and its components. Thermochimica Acta, v.35I, n. I-2, p.I77-18I, 2000.

VILAS BOAS, M. A.; CARNEIRO, A. DE C. O.; VITAL, B. R.; CARVALHO, A. M. M. L.; MARTINS, M. A. Efeito da temperatura de carbonização e dos resíduos de macaúba na produção de carvão vegetal. Scientia Forestalis, v.38, n. 87, p. $481-490,2010$.

WANG, C.; LIU, Y.; ZHANG, X.; CHE, D. A study on coal properties and combustion characteristics of blended coals in northwestern China. Energy \& Fuels, v.25, n. 8, p.3634-3645, $201 \mathrm{I}$.

WANG, C.; LIU, Y.; ZHANG, X.; CHE, D. Pyrolysis and combustion characteristics of coals in oxyfuel combustion. Applied Energy, v.97, p.264-273, 2012.

WARD, C. R.; ZHONGSHENG, L.; GURBA, L. W. Comparison of elemental composition of macerals determined by electron microprobe to whole-coal ultimate analysis data. International Journal of Coal Geology, v.75, n. 3, p. I57-165, 2008.

XIANG-GU, L.; BAO-GUO, M.; LI, X.; ZHEN-WU, H.; XIN-GANG, W. Thermogravimetric analysis of the cocombustion of the blends with high ash coal and waste tyres. Thermochimica Acta, v.44I, n. I, p.79-83, 2006.

XIONG, S.; ZHANG, S.; WU, Q.; DONG, A.; CHEN, C. Investigation on cotton stalk and bamboo sawdust carbonization for barbecue charcoal preparation. Bioresource Technolology, v. I52, p.86-92, 2014.

YANG, H.; YAN, R.; CHEN, H.; LEE, D. H.; ZHENG, C. Characteristics of hemicellulose, cellulose and lignin pyrolysis. Fuel, v.86, n. I2-I3, p. I78I-I 788, 2007. 
